\title{
Case report of goose haemorrhagic polyomavirus in 4-day-old goslings indicating vertical transmissibility
}

\author{
Attila Farsang ${ }^{1}$, Sandor Bernath ${ }^{1}$, Mihaly Dobos-Kovacs ${ }^{2}$ \\ ${ }^{1}$ Central Agricultural Office, Directorate of Veterinary Medicinal Products, \\ Budapest, Hungary \\ ${ }^{2}$ Department of Pathology and Veterinary Forensic, Faculty of Veterinary Sciences, Szent Istvan University, \\ Budapest, Hungary \\ Received February 18, 2010 \\ Accepted April 6, 2011
}

\begin{abstract}
Haemorrhagic nephritis and enteritis of geese (HNEG) is a fatal disease caused by goose haemorrhagic polyomavirus (GHPV). The aim of our study was to investigate a field outbreak of HNEG by pathological methods and real-time PCR assay using light upon extension (LUX PCR) with special regard to the possibility of vertical transmission. This is the first time that presence of GHPV was confirmed in goslings that died within 4 days after hatching showing typical symptoms of HNEG, which indicates vertical transmissibility as the shortest incubation period of HNEG is 6 days. The way of viral transmission is a key issue and thus the disease control measurements and HNEG epizootiology may be revised based on the findings of this study.
\end{abstract}

Avian pathogens, nephritis, enteritis, LUX PCR, pathology

Haemorrhagic nephritis and enteritis of geese (HNEG) is a fatal disease caused by goose haemorrhagic polyomavirus (GHPV). Since 1969, the first report of the disease by Bernath and Szalai (1970), the disease has spread through goose breeding areas of Germany (Schettler 1977; Miksch et al. 2002), Southern France (Schettler 1977; Guerin et al. 1999) and Hungary (Palya et al. 2004) with an epizootic pattern.

The horizontal transmission of GHPV was earlier confirmed by Bernath and Szalai (1970) whereas the vertical route has not been proved; however, some observations posed the possibility that GHPV could be vertically transmitted. Firstly, Schettler (1980) supposed, that GHPV might have been circulating for almost a lifetime in the blood of infected geese, as HNEG was first detected in goslings immunised with reconvalescent anti-Derzsy disease sera obtained from apparently healthy geese. It may allow the GHPV to spread via infected eggs. Secondly, death of goslings at the age of 4 days was observed in flocks affected by HNEG, but GHP virions were not reported in these birds. Based on the death occurred at the age of 4 days, Palya et al. (2004) postulated the vertical transmission of HNEG because earlier studies showed that the shortest incubation period was 6 days after subcutaneous infection of 1-day-old goslings in an experimental infection study (Bernath and Szalai 1970).

In the present report, investigation of a field outbreak among 4-day-old goslings is reported, providing further supportive data regarding the vertical transmissibility of GHPV.

\section{Materials and Methods}

Birds

The goslings examined originated from a goose farm in the Hortobagy region of Hungary, where 100 of 7033 4-day-old Hortobagy White goslings died showing symptoms of nephritis and enteritis in 2008.

Pathological examinations

A total of 20 carcasses were sent to the Department of Pathology and Veterinary Forensic, Faculty of Veterinary

Address for correspondence:

Dr. Attila Farsang

Central Agricultural Office

Directorate of Veterinary Medicinal Products, Budapest

Hungary
Phone: +3614330330

Fax: +3612622839

E-mail: farsanga@oai.hu

http://www.vfu.cz/acta-vet/actavet.htm 
Sciences, Szent Istvan University, for pathological examination. Brain and liver specimens were plated onto blood agar (Merck, USA) for testing the presence of bacteria.

Organ specimens and isolation of DNA

Tissue samples of intestine, kidney, lung, brain, liver, spleen and Bursa Fabricii originating from 4-day-old goslings were investigated. The samples were maintained separately.

The organ specimens from carcasses were homogenised, $1 \mathrm{~g}$ tissue in $8 \mathrm{ml}$ phosphate-buffered saline without calcium and magnesium (PBS). The homogenate was mixed with penicillin, streptomycin and gentamicin $(30 \mathrm{IU} / \mathrm{ml}$ each). The samples were centrifuged at $5000 \times \mathrm{g}$ for $5 \mathrm{~min}$ and $166 \mu \mathrm{l}$ of supernatant was added to $245 \mu 1$ PBS, $83 \mu 16 \times$ proteinase buffer and $5 \mu 1$ proteinase $\mathrm{K}$ (Sigma, USA). The mixture was incubated at $55^{\circ} \mathrm{C}$ for $1 \mathrm{~h}$. The DNA was extracted by TrizolTM (Invitrogen, USA) according to manufacturer's instructions. The precipitated DNA was pelleted at $12,500 \times g$ for $15 \mathrm{~min}$, washed once with $400 \mu \mathrm{l}$ of $70 \%$ ethanol, dried and dissolved in $25 \mu \mathrm{ldd} \mathrm{H}_{2} \mathrm{O}$.

PCR

PCR assays were carried out on intestine, kidney, lung, brain, liver, spleen and Bursa Fabricii. In order to screen for GPV PCR using primers and reaction conditions published by Sirivan et al. (1998) was used.

To detect GHPV in the samples, a real-time PCR assay using light upon extension (LUX PCR) technique was applied. Primers (FOR: 5' cgg cGC ACC ATC TTT ATC AAG CcG-FAM 3'; REV: 5' GGT TGC ACC ACC TCT GAA GGA 3') were designed based on VP1 gene of GHPV (GenBank accession No.: AY327112). PCR was carried out in a MiniOpticon (BioRad, USA), the reaction mixture contained $5 \mu 10 \times$ Titanium Taq buffer, $0.5 \mu \mathrm{l}$ of each dNTP $(10 \mathrm{mM}), 20 \mathrm{pmol}$ of each primer and $\mathrm{ddH}_{2} \mathrm{O}$ up to $25 \mu \mathrm{l}$. Amplification was performed with a thermal profile of $94{ }^{\circ} \mathrm{C}$ for $15 \mathrm{~s}, 60{ }^{\circ} \mathrm{C}$ for $30 \mathrm{~s}$ and $72^{\circ} \mathrm{C}$ for $30 \mathrm{~s}$. This cycle profile was repeated $35 \times$ and finally a melting curve analysis of the amplified PCR products was performed from $70{ }^{\circ} \mathrm{C}$ to $90^{\circ} \mathrm{C}$ in $0.5{ }^{\circ} \mathrm{C} / 10 \mathrm{~s}$ increase. The melting curve was compared to a well-characterised positive control with known nucleotide sequence, which was amplified together with samples in the same assay.

\section{Results and Discussion}

Haemorrhagic enteritis (Plate IV, Fig. 1), renal haemorrhages and ascites in the abdominal cavity were revealed in all examined carcasses. Considering the fact that haemorrhages in 4-day-old goslings can be caused by numerous agents such as Salmonella anatum, S. enteriditis, S. hadar, S. typhimurium and bacterial septicaemia, brain and liver specimens were plated onto blood agar. Furthermore, PCR for GPV and GHPV was carried out.

Both bacteriological tests and PCR to detect GPV proved to be negative, while PCR for GHPV gave positive signals on a total number of 20 samples including liver, spleen, kidney, intestine and Bursa Fabricii specimens.

The severity and incubation period of the disease depend on 1) the amount of infective virions; 2) the age of the susceptible bird. In an infection experiment 1-day-old (Group 1) and 14-day-old geese (Group 2) were infected with GHPV. During the 30-day observation period all goslings of Group 1 died within 6 and 8 days post infection, while the mortality was only 50\% in Group 2 (Bernath and Szalai 1970) indicating that geese can be latently infected, contributing to the virus spread either by virus shedding or by producing infected eggs, but neither experimental nor field-related observations have proved these possibilities to date.

This is the first report when the presence of GHPV was confirmed by pathological examination and LUX PCR in goslings that died at the age of 4 days showing typical symptoms of HNEG that originated from a field outbreak with well-documented disease history. The findings of the present study are clearly indicative to vertical transmission of GHPV and in concordance with our previous report when two experimentally infected geese embryos were able to hatch showing poor physical conditions and after manifesting HNEG-related pathological lesions died of HNEG at age of 4 days post-hatching (DobosKovacs et al. 2005). GHPV was detected from cloacal swabs by PCR (Bernath et al. 2006).

Based on our study, the vertically transmitted GHPV may infect goslings in the most susceptible life period, therefore, vertical transmissibility of GHPV is of major importance for both disease control measurements and HNEG epizootiology. 


\section{Acknowledgements}

The authors would like to thank Dr. Gabor Kulcsar for critical reading of the manuscript.

\section{References}

Bernáth S, Szalai F 1970: Investigations for clearing the etiology of the disease appeared among goslings in 1969. I. Animal infection experiments (in Hungarian, with English abstract). Hungarian Veterinary Journal 25: $531-536$

Bernáth S, Farsang A, Kovács A, Nagy E, Dobos-Kovács M 2006: Pathology of goose haemorrhagic polyomavirus infection in goose embryos. Avian Pathol 35: 49-52

Dobos-Kovács M, Horváth E, Farsang A, Nagy E, Kovács A, Szalai F, Bernáth S 2005: Haemorrhagic nephritis and enteritis of geese: pathomorphological investigations and proposed pathogenesis. Acta Vet Hung 53: 213-223

Guerin JL, Pingret JL, Gelfi J, Dubois L, Sans P, Vuillaume A, Boucraut-Baralon C, Bertagnoli S 1999 : Isolation of avian polyomavirus, associated with hemorrhagic nephritis and enteritis of geese. Proceedings of the 1st World Waterfowl Conference (pp. 66-271). Tachung, Taiwan.

Miksch K, Grossmann E, Kohler K, Johne R 2002: Detection of goose haemorrhagic polyomavirus (GHPV) in flocks with haemorrhagic enteritis and nephritis of geese in southern Germany (in German). Berl Munch Tierarztl 115: 390-394

Palya V, Ivanics E, Glávits R, Dan A, Mato T, Zarka P 2004: Epizootic occurrence of haemorrhagic nephritis enteritis virus infection of geese. Avian Pathol 33: 244-250

Schettler CH 1977: Detection en France de la nephrite hemorragique et enterite de l'oie (NHEO) [in French]. Recueil de Medecine Veterinaire D'Alfort 153: 353-355

Schettler CH 1980: Klinik und Pathologie der hamorrhagischen Nephritis und Enteritis der Ganse [in German]. Tieraerztl Prax 8: 313-320

Sirivan P, Obayashi M, Nakamura M, Tantaswasdi U, Takehara K 1998: Detection of goose and muscovy duck parvoviruses using polymerase chain reaction-restriction enzyme fragment length polymorphism analysis. Avian Dis 42: 133-139 
Plate IV

Farsang A. et al.: Case report of ... pp. 255-257

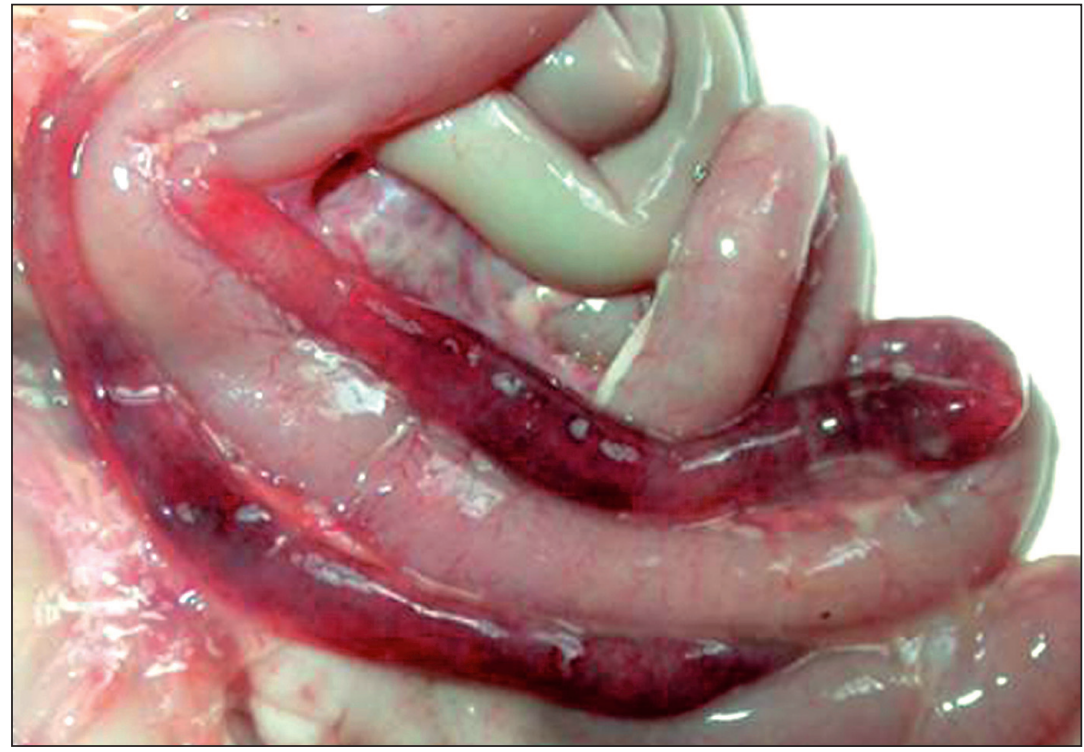

Fig. 1. Haemorrhages on the mucosa of caecum. 